\title{
EFFECT OF SOME LACTIC ACID BACTERIA ON SOME PARAMETERS OF THE SILKWORM , BOMBYX MORI L.
}

(1) Nagat H. Soliman \& (2) Warda M. A. Ebid

(1) Plant Protection Department, Faculty of Agriculture, El Fayoum University, Egypt.

(2) Dairy Science Department, Faculty of Agriculture, El Fayoum University, Egypt.

\begin{abstract}
Effect of lactic acid bacteria (Lactobacillus rhamnoses, Lactobacillus paracasei and Lactobacillus acidophilus) as food additives on some parameters of Bombyx mori L. was carried out . Experimental product of Lactic acid bacteria was dissolved in distilled water to prepare one concentration $(5 \mathrm{mg} / \mathrm{ml}$.) from bacteria in addition to yoghurt and milk. The obtained results showed that, Lactobacillus acidophilus occupied the first category for improving the most studied parameters of $B$. mori when comparing to control. Where the 5th instar larval weights were $2.159 \mathrm{~g}$ compared to $2.002 \mathrm{~g}$ in control, effective rate of rearing recorded $82.00 \%$ compared to $78.00 \%$ in control and total haemolymph protein recorded $64.00 \mathrm{mg} / \mathrm{ml}$. compared to $60.99 \mathrm{mg} / \mathrm{ml}$. in control. Cocoon indices registered $1.101 \mathrm{~g}, 0.209 \mathrm{~g}$ and $18.98 \%$ for cocoon weight, cocoon shell weight and cocoon shell ratio comparing to $1.005 \mathrm{~g}$, $0.177 \mathrm{~g}$ and $17.61 \%$ for the control respectively.
\end{abstract}

\section{INTRODUCTION}

The silkworm is the larva or caterpillar of the domesticated silk moth, Bombyx mori belonging to the Family Bombycidae. It is an important economic insect since it is the producer of silk. Sericulture or silk farming is the rearing of silkworms for the production of raw silk although there are several commercial species of silkworms, Bombyx mori is the most widely used and intensively studied.

Probiotics are organisms and substances which contribute to intestinal microbial balance (Parker, 1974). Lactic acid bacteria (LAB) are a group of Gram-positive, non-sporulating bacteria that includes species of Lactobacillus, Leuconostoc, Pediococcus and Streptococcus. Dietary LAB refers to those species and strains that are used in food and feed fermentation processes. The term LAB does not reflect a phyletic class, but rather a group of organisms that are defined by their ability to produce a common end product lactic acid from the fermentation of sugars. LAB have limited biosynthetic abilities, and require pre-formed amino acids, $\mathrm{B}$ vitamins, purines, pyrimidines and, usually a sugar as a carbon and energy source. These nutritional requirements restrict their habitats to those in which the required compounds are abundant (Oh $\boldsymbol{e t}$ al., 2000). The gut probiotics are involved in the digestive utilization of feeds and detoxification of metabolite, stimulation of non-specific immune system.

Fayoum J. Agric. Res. \& Dev., Vol. 32, No.2, July, 2018 
They also promote the production of vitamins and increase host resistance and compete with pathogenic bacteria by producing organic and antibiotic substance. The lactobacillus plantarum is a probiotic which improves the cocoon production of mulberry silkworm B. mori (Singh et al., 2005). The present study highlights the effect of some lactic acid bacteria on some the economical parameters of the silkworm B. mori.

\section{MATERIALS AND METHODS}

The effect of some lactic acid bacteria (Lactobacillus rhamnoses, Lactobacillus paracasei and Lactobacillus acidophilus) on rearing performance of silkworm, Bombyx mori L., were studied at Plant Protec. Dept. Fac. of Agric., Fayoum Univ. during spring season (12-4 /2-6) of 2016. Egg box of silkworm, B. mori L. (local hybrid) was obtained from the Seric. Res. Dept., Plant Protec. Res. Inst, Agric. Res. Center. Dokki, Giza. Lyophilized strains, Lb. paracasei NRRL-B-4560 and Lb. rhamnoses NRRLB-442, were obtained from Dairy Microbiology Laboratory National Research Center (NRC), Dokki, Cairo, Egypt. , Lb. acidophilus (type La 5) was obtained from Chr. Hansen's Laboratories, Copenhagen, Denmark. $5 \mathrm{mg}$ of the above mentioned bacteria in addition to yoghurt and milk $/ \mathrm{ml}$ of distilled water were prepared. Larvae of $B$. mori L. were reared on fresh mulberry leaves (Morus alba var. indicia) grown in the farm of faculty of Agriculture at Fayoum (at Dar El Ramd region ) under laboratory conditions $\left(26 \pm 2^{\circ} \mathrm{C}\right.$, $70 \pm 5 \% \mathrm{RH})$. At the beginning of the $4^{\text {th }}$ instar, larvae were divided into five groups (in addition to the control). Each group contained five replicates (each of twenty larvae). Each replicate was reared in carton tray $(30 \times 15 \times 4 \mathrm{~cm})$. larvae were fed on one of the five experimental products day after day during $4^{\text {th }} \& 5^{\text {th }}$ larval instars.

Mulberry leaves were sprayed with one of the experimental products after drying on ambient air temperature for one minute, while the control was fed on mulberry leaves sprayed with distilled water. The tested parameters were recorded for all replications of treatments and control i.e: 5th instar larval weights, effective rate of rearing, cocoon weights, cocoon shell weights and cocoon shell ratio were calculated and total haemolymph protein were recorded. was calculated. Data was analyzed by ANOVA through statistical package for social science (SPSS) according to Berkowitz and Allaway, 1998 to find out the significance between treated and control. Means were separated by (L.S.D at $0.05 \%$ ).

\section{RESULTS AND DISCUSSION}

\section{5th instar larval weights:}

According to data in table (1) the means of the 5th instar larval weights were ranged between $2.000 \mathrm{~g}$ for milk and $2.159 \mathrm{~g}$ for Lactobacillus acidophilus treatments. The obtained results are in general agreement with

Fayoum J. Agric. Res. \& Dev., Vol. 32, No.2, July, 2018 
Sekar et al.( 2011) and Rahul et al.(2017) whom found improving in larval weight of $B$. mori when using mulberry leaves treated with Probiotic bacteria (Lactobacillus rhamnosus ATCC 9595, Lactobacillus acidophilus ATCC) and Lactobacillus sporogenes, Lactobacillus acidophilus, Bacillus licheniformis, Bacillus subtilis \& Saccharomyces cerevisiae, .

\section{Effective rate of rearing:}

Data presented in table (1) showed no significant change in the treated groups with Lactic acid bacteria when compared to control one for the effective rate of rearing. The highest rate $(82.00 \%)$ has been obtained in Lactobacillus acidophilus treatment. Similar observation was reported by Rahul et al.(2017) as effective rate of rearing of B. mori larvae was improved when mulberry leaves were treated with Probiotic bacteria (Lactobacillus rhamnosus ATCC 9595 and Lactobacillus acidophilus ATCC 4356).

\section{Total haemolymph protein:}

According to data in table (1) total haemolymph protein was increased in the treated groups with Lactic acid bacteria comparing to the control, it recorded $64.00 \mathrm{mg} / \mathrm{ml}$ when larvae treated with Lactobacillus acidophilus comparing to $60.99 \mathrm{mg} / \mathrm{ml}$ in control. The obtained results are supported by Rexin and Vasantha (2017) when used mulberry leaves treated with 1, 3 and 5\% concentration of Lactic acid bacillus.

TABLE (1):Effect of feeding Bombyx mori L. larvae on mulberry leaves treated with Experimental products of bacteria on some parameters.

\begin{tabular}{|c|c|c|c|}
\hline Experimental products & \multicolumn{3}{|c|}{ Parameters } \\
\cline { 2 - 4 } (5 mg/ml of water). & $\begin{array}{c}\text { Means of 5th instar } \\
\text { larval weights } \\
(\mathrm{g}) \pm \mathrm{SE}\end{array}$ & $\begin{array}{c}\text { Means of effective } \\
\text { rate of rearing }(\%)\end{array}$ & $\begin{array}{c}\text { Total haemolymph } \\
\text { protein }(\mathrm{mg} / \mathrm{ml} .) .\end{array}$ \\
\hline Lactobacillus rhamnoses & $2.020 \pm 0.0030 \mathrm{~b}$ & $80.00 \pm 1.4500$ & $63.54 \pm 2.789 \mathrm{ab}$ \\
\hline Lactobacillus acidophilus & $2.159 \pm 0.0021 \mathrm{a}$ & $82.00 \pm 1.4378$ & $64.00 \pm 2.008 \mathrm{a}$ \\
\hline Lactobacillus Paracasei & $2.005 \pm 0.0087 \mathrm{~b}$ & $80.00 \pm 1.4553$ & $62.90 \pm 2.545 \mathrm{ab}$ \\
\hline yoghurt & $2.011 \pm 0.0012 \mathrm{~b}$ & $79.00 \pm 1.6009$ & $62.78 \pm 2.776 \mathrm{ab}$ \\
\hline milk & $2.000 \pm 0.0066 \mathrm{~b}$ & $78.00 \pm 1.8990$ & $60.03 \pm 2.770 \mathrm{~b}$ \\
\hline Control & $2.002 \pm 0.0025 \mathrm{~b}$ & $78.00 \pm 1.2344$ & $60.99 \pm 2.009 \mathrm{~b}$ \\
\hline F test & $* *$ & --- & $*$ \\
\hline LSD at 0.05\% & 0.101 & --- & 3.000 \\
\hline
\end{tabular}

Cocoon weights, cocoon shell weights and cocoon shell ratio:

Data in table (2) represent the means of cocoon, cocoon shell weights and cocoon shell ratio as follow:

\section{Cocoon weights:}

The mean weight of the cocoon was maximum $(1.101 \mathrm{~g})$ in Lactobacillus acidophilus treatment with significant difference compering to

Fayoum J. Agric. Res. \& Dev., Vol. 32, No.2, July, 2018 
control. The obtained results in accordance with Sekar et al.( 2011) who found, increase in cocoon weight of B. mori when using mulberry leaves treated with Probiotic bacteria (Lactobacillus rhamnosus ATCC 9595 and Lactobacillus acidophilus ATCC 4356, Rahul et al.( 2017) when using mulberry leaves treated with Lactobacillus sporogenes, Lactobacillus acidophilus, Bacillus licheniformis, Bacillus subtilis \& Saccharomyces cerevisiae.

\section{Cocoon shell weights:}

The cocoon shell weights were $0.209 \mathrm{~g}$ in Lactobacillus acidophilus treatment compering to $0.177 \mathrm{~g}$ in control. In these experiment shell weight of larvae treated with Lactobacillus acidophilus was significantly increased compered with control. The obtained results agreement with Sekar et al.(2011) when using mulberry leaves treated with Lactobacillus sporogenes, Lactobacillus acidophilus, Bacillus licheniformis, Bacillus subtilis \& Saccharomyces cerevisiae.

\section{Cocoon shell ratio:}

Cocoon shell ratio was $18.78 \%$ and $17.61 \%$ of Lactobacillus acidophilus treatment and control respectively. In these experiment cocoon shell ratio of larvae treated with Lactobacillus acidophilus was in significantly increased compered with control. The obtained results are in general agreement with the findings of Rahul et al.(2017) who found that, increasing the cocoon shell ratio of $B$. mori when using mulberry leaves treated with Probiotic bacteria (Lactobacillus rhamnosus ATCC 9595 and Lactobacillus acidophilus ATCC 4356).

TABLE (2):Effect of feeding Bombyx mori L. larvae on mulberry leaves treated with Experimental products of bacteria on cocoon parameters.

\begin{tabular}{|c|c|c|c|}
\hline Experimental products & \multicolumn{3}{|c|}{ Parameters } \\
\cline { 2 - 4 } & $\begin{array}{c}\text { The means of } \\
\text { mg/ml of water). } \\
\text { cocoon weights } \\
(\mathrm{g}) .\end{array}$ & $\begin{array}{c}\text { The means of cocoon } \\
\text { shell weights }(\mathrm{g}) .\end{array}$ & $\begin{array}{c}\text { The means of cocoon } \\
\text { shell ratio }(\%) .\end{array}$ \\
\hline Lactobacillus rhamnoses & $1.009 \pm 0.001 \mathrm{~b}$ & $0.187 \pm 0.033 \mathrm{ab}$ & $18.53 \pm 1.024$ \\
\hline Lactobacillus acidophilus & $1.101 \pm 0.001 \mathrm{a}$ & $0.209 \pm 0.032 \mathrm{a}$ & $18.98 \pm 1.011$ \\
\hline Lactobacillus Paracase & $1.022 \pm 0.003 \mathrm{~b}$ & $0.190 \pm 0.045 \mathrm{ab}$ & $18.59 \pm 1.009$ \\
\hline yoghurt & $1.010 \pm 0.022 \mathrm{~b}$ & $0.180 \pm 0.014 \mathrm{~b}$ & $17.82 \pm 1.088$ \\
\hline milk & $1.003 \pm 0.004 \mathrm{~b}$ & $0.175 \pm 0.018 \mathrm{~b}$ & $17.44 \pm 1.090$ \\
\hline Control & $1.005 \pm 0.000 \mathrm{~b}$ & $0.177 \pm 0.022 \mathrm{~b}$ & $17.61 \pm 1.088$ \\
\hline F test & $* *$ & $*$ & --- \\
\hline LSD at 0.05\% & 0.076 & 0.023 & --- \\
\hline
\end{tabular}

Fayoum J. Agric. Res. \& Dev., Vol. 32, No.2, July, 2018 


\section{REFERENCES}

Berkowitz D. and Allaway A. (1998). Statistical package for social sciences (SPSS), Version 7.5 for Windows NT/Windows 95:130-132.

Oh, S.; Kim, S. H. and Worobo, R. W. (2000). Characterization and purification of a bacteriocin produced by a potential probiotic culture, Lactobacillus acidophilus 30SC. J. Dairy Sci., 83: 27472752.

Parker, R. B. (1974). Probiotics the other half of the antibiotic story.Animal Nutrition and Health, 29: 4-8.

Rahul, K. ; Roy, G. ; Hossain, Z. and Trivedy, K.(2017). Impact of probiotics Lactobacillus rhamnosus ATCC 9595 and Lactobacillus acidophilus ATCC 4356 on the economic traits of silkworm Bombyx mori L. Imperial Journal of Interdisciplinary Research,3(3):11151117.

Rexin, A. and Vasantha, R. (2017). Effect of sporlac on protein content of silkworm Bombyx mori L. International Journal of Emerging Trends in Science and Technology, 4(2): 4994-4997.

Sekar, P.; Balasundaram, A. and George, J. (2011). A study on immunomodulation and health enhancement in Bombyx mori subjected to supplementary feeding with a probiotic consortium . International Journal of Current Research, 33( 2) :006-016.

Singh, K.K; Chauhan,R.M.; Pande,A.B.; Gokhale S.B. and Hegde,N.G. (2005). Effect of use of Lactobacillus plantarum as a probiotics to improve cocoon production of mulberry silkworm, Bombyx mori (L.).J. Basic Appl.Sci. 1:1-8.

Fayoum J. Agric. Res. \& Dev., Vol. 32, No.2, July, 2018 


$$
\begin{aligned}
& \text { دراسة تأثير بكتريا حمض اللاكتك على بعض صفات دودة الحرير التوتية. }
\end{aligned}
$$

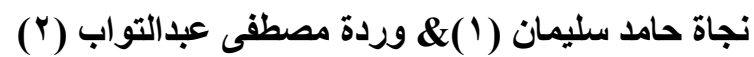

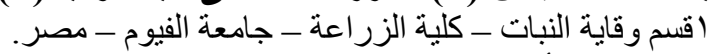

$$
\begin{aligned}
& \text { كقسم علوم الألبان - كلية الزر اعة الزراع - جامعة الفيوم - مصر. }
\end{aligned}
$$

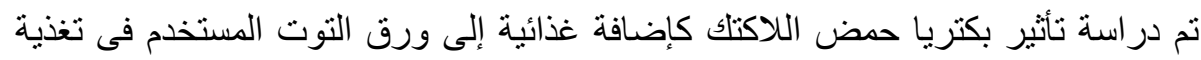

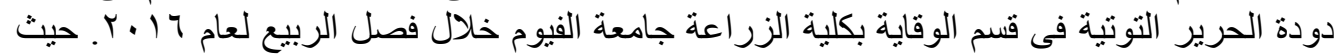

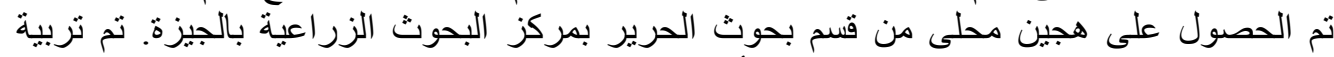

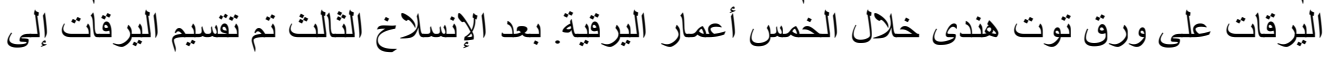

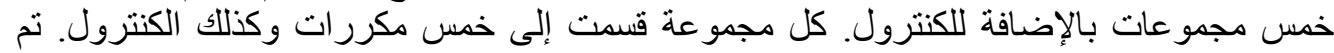

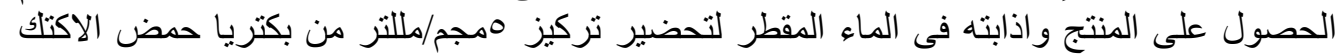

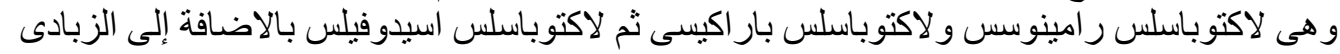

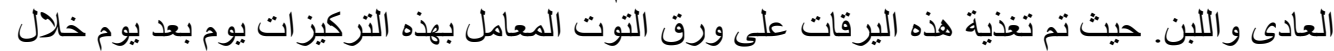

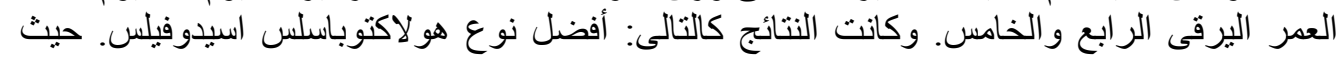

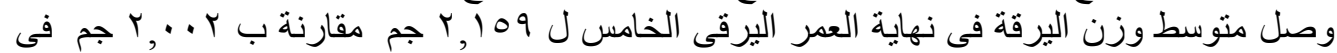

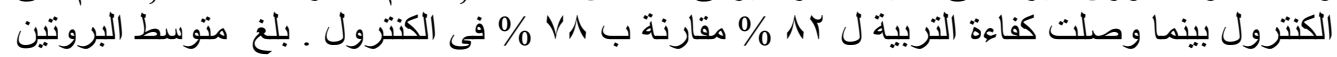

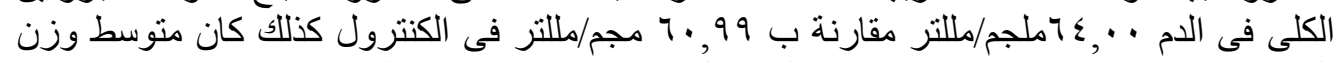

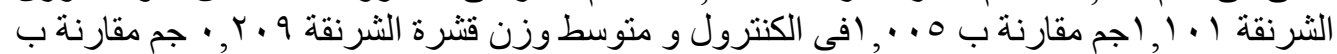
هو , IVV

Fayoum J. Agric. Res. \& Dev., Vol. 32, No.2, July, 2018 